\title{
Organizational mechanism for the formation of an innovative enterprise in the conditions of a new technological structure
}

\section{T. Kapeliushna}

\author{
State University of Telecommunications, Kyiv, Ukraine
}

Corresponding author. E-mail: e-skr@ukr.net

Paper received 29.11.19; Accepted for publication 10.12.19.

\section{https://doi.org/10.31174/SEND-HS2019-213VII35-03}

\begin{abstract}
Annotation. The article presents technological patterns, economic cycles, provides their characteristics, reveals the relationship between economic cycles and periods of technological development. The importance of an innovative enterprise in the conditions of a new technological structure and the need to create favorable conditions for its functioning, which will lead to more active innovative development, the introduction of innovations
\end{abstract}

Keywords: innovative enterprise, organizational mechanism, technological structure, intellectual property, innovation.

Introduction. The existence of society today is characterized by an active search for a new, previously unknown, that will allow us to achieve new achievements and improve. Market entities, in particular enterprises that are trying to actively and dynamically develop, react accordingly. They react to changes and take into account factors in order to improve production and increase financial and economic indicators.

A modern enterprise seeks to ensure a certain uniqueness, which will form its special image and guarantee long-term functioning in a competitive environment. An enterprise can strengthen its position through a new, progressive, innovative approach to the production or provision of services. The fourth technological revolution and the sixth technological order forms a new wave of economic development on a global scale. The central role will be played by an innovative enterprise. It is necessary to take into account changes in legislation, focus on highly developed countries. This kind of vector set by the country actualizes the formation of innovative enterprises that will take into account global economic, legal, social, technological trends in the context of a new technological structure.

Sources review. The problems of innovative development of enterprises are covered in the scientific works of many scientists. In particular, the theoretical provisions are devoted to the work of scientists: Kristen K., Mansfield, R. Nelson, Nikoluk A.N., Antyushkina V.V., Peters T.E., K. Freeman, research on the innovative activity of enterprises was carried out by I Schumpeter., Biryukov A.V., R. Solow,. Kondratiev M.D.

Aspects of the formation of the innovative potential of enterprises are presented in the works: Verbitskaya V.I., Chugriy N.A., Kutsik V.I., Pishenina T.I. The works of Shevchenko A.N., Belovodsky A.A., Gudz E.E. devoted to the problems of the functioning of innovative enterprises. Changing the technological structure and global integration processes actualize the need to develop an organizational mechanism for the formation of an innovative enterprise in the context of a new technological structure.

Purpose. The aim of this paper is to develop an organizational mechanism for the formation of an innovative enterprise in the conditions of a new technological structure to ensure its normal functioning

Methods. The article uses a comparison, reverse synthesis, identification methods.
Results and discussions. A necessary basis for a modern enterprise is innovation. In particular, the experience of numerous developed countries indicates that in times of economic change, scientific and technological progress, a necessary element for stabilizing the functioning of the country is the activation of innovative processes and market reforms.

The concept of "innovation" means newly (applied) and (or) improved competitive technologies, products or services, as well as organizational and technical solutions of a production, administrative, commercial or other nature. They improve the structure and quality of production and (or) the social sphere.

Innovative enterprise (innovation center, technopark, technopolis, innovative business incubator, etc.) - an enterprise (business combination) develops, manufactures and sells innovative products and (or) products or services, the volume of which in monetary terms exceeds 70 percent its total volume of products and (or) services [1].

The maximum should be institutional assistance to create such innovative enterprises. In the chain, the result of intellectual labor - an innovative product should use the country's production factors. Minimize the use of other people's ideas, development and tools to create it. Such innovative enterprises will become the key to the country's stable development [7]. It will be a leading country, otherwise it will develop poorly, develop products at the expense of donor countries, use their discoveries, and innovative developments. Purchase of developments, implementation of innovative products created by foreign enterprises will lead to the country becoming a consumer of an innovative product - an outsider country for scientific discoveries, innovative developments and the introduction of innovative products.

Table 1. Leading countries in the field of innovation by region for 2019

\begin{tabular}{|c|c|c|c|}
\hline \multicolumn{4}{|c|}{ Regions } \\
\hline $\begin{array}{c}\text { North } \\
\text { America }\end{array}$ & Europe & $\begin{array}{c}\text { North Africa } \\
\text { and West Asia }\end{array}$ & $\begin{array}{c}\text { Southeast, East } \\
\text { Asia and Oceania }\end{array}$ \\
\hline \multicolumn{4}{|c|}{ Countries } \\
\hline USA & Switzerland & Israel & Singapore \\
\hline Canada & Sweden & Cyprus & Republic of Korea \\
\cline { 2 - 4 } & Netherlands & $\begin{array}{c}\text { United Arab } \\
\text { Emirates }\end{array}$ & Hong Kong, China \\
\hline
\end{tabular}

Today, the leading countries in the field of innovation are the USA, Canada, Switzerland, Sweden, the Nether- 
lands, Israel, Cyprus, the United Arab Emirates, Singapore, the Republic of Korea, Hong Kong, and China. Leading countries in the field of innovation are presented in table $1[9,11]$.

The new technological structure coincides with a downward long-term wave of economic development. Therefore, it is necessary to reorient production taking into account these changes.

Creation of new conditions for the functioning of an innovative enterprise is a necessity, has a universal character of changes in the world. This is due to the fact that the third scientific and technological revolution is ending [2]. Professor Klaus Schwab indicated that significant transformations are envisaged that will fundamentally change life, work, communication, radical changes will occur in all sectors, established norms and relationships will be destroyed, and procedures for updating them will not be offered.

An analysis of the stages of economic development, the level of technology development, as well as discoveries, inventions, we can trace the trend of their influence on economic growth. Schumpeter's works became the basis for the formation of theoretical positions on the close relationship between entrepreneurship and technological development, as well as the active introduction of innovations. In his works, the company played an important role in the emergence of innovative products, their use [4].

The scientific and technological revolution, technological patterns and the periodization of economic cycles allow us to conclude that the economy is in a downward phase of its development cycle.

The next long-term wave of Kondratiev begins in 2020. Research is being conducted, discoveries and implementation of biological technologies are taking place. According to the technological structure, at the beginning of the 20th century, nanotechnologies, bio-, and nuclearcell technologies appear, which, in turn, proves the assumption that there is a relationship between the economy and technological changes $[3,5,6]$.

Technical progress, the importance of innovative development and science as its component enhances the role of innovative enterprises in modern conditions.

An important element in the formation of an innovative enterprise is the legal support. In developed countries such as the United Kingdom and Germany, such conditions have been created that the promotion of innovative enterprises is a priority in the structure of the economy. Almost $50 \%$ of the programs of the EU countries include policies in the field of scientific research and technology, as evidenced by a number of framework programs, which are the main tools for financing research. Effective Now Horizon 2020: EU Research and Innovation Framework [10]

Horizon 2020 is the largest program in the history of the European Union aimed at financing research and innovation, with a total budget of about 80 billion euros, designed for seven years (from 2014 to 2020). It replaced the 7th EU Framework Program for Research and Technological Development (7RP), which ran from 2007 to 2013. The program includes a tool to support small and medium-sized enterprises, which is aimed at all types of innovative initiatives for small and medium-sized enter- prises, which demonstrate the desire for development, growth and international reach. Within the framework of such projects, phased financing of the full innovation cycle is provided, as well as additional training and support services. Conditions of participation: at least 1 commercial small or medium-sized enterprise registered in an EU member country or a country associated with the Horizon 2020 program [12].

The program provides a single set of simplified rules and minimizes multi-level paper-based paperwork.

The program is designed in such a way as to ensure ease of participation of organizations in it, primarily for higher education institutions, enterprises, regardless of their size and territorial affiliation. The developers of the program approached the issues of activating innovative enterprises and innovative activities from the right side, namely financing, realizing that new products will ensure high competitiveness of enterprises, high demand for an innovative product, creating new jobs, increasing tax payments and, as a result, improving the level of life of the population and profit for innovative enterprises.

That is, it is necessary to introduce programs and measures of economic policy, which will become the impetus for the emergence of innovative enterprises in Ukraine.

In order to work efficiently, enterprises must take into account the following factors: environmental, technological, social, political, market, economic, environmental, international and technogenic. The latter, as we noted above, have a close relationship with the emergence of innovative enterprises. Thanks to new knowledge, technological solutions, the use of new innovative technologies, the development and competitiveness of a modern enterprise will be achieved. In the near future, key technologies will be security and communications, as well as artificial intelligence. But the modern world also requires sustainable development, that is, one that will not threaten future generations, and this is one of the important components of creating a modern innovative enterprise.

The innovative process of the enterprise includes: financing of scientific research, creation of meeting places for the exchange of experience between experts and developers and scientists, state support for the creation and functioning of elements of innovative infrastructure in higher education institutions, scientific institutions and other subjects of innovative activity.

Ensuring the formation of an innovative enterprise provides for stimulating enterprises to scientific and scientific-technical developments with the involvement of experts, as well as scientists conducting scientific research in the framework of the outlined topics. In addition, the state should take an active part, providing support to the subjects of the innovation process through the creation of technological platforms as a communication mechanism for the public and private customer of innovations; to simplify reporting and reduce the amount of taxation on personal income and remuneration of the newly small innovative enterprise.

It is possible to achieve the intensification of the development of innovative enterprises with the right approach to the formation of the mechanism of an innovative enterprise. The state of the valley will create conditions and institutions that will search for scientists and 
investors in certain industries who are interested in obtaining an innovative product that society needs. In parallel, a specialist in intellectual property management should work, who will carry out a formal transfer of rights to use an innovative product and the possibility of carry- ing out production as well as commercial operations on an innovative product. It is important to analyze the environment, investment climate, risks, reserves of the enterprise, analyze the development of science, forecast risks, select investors and research institutions.

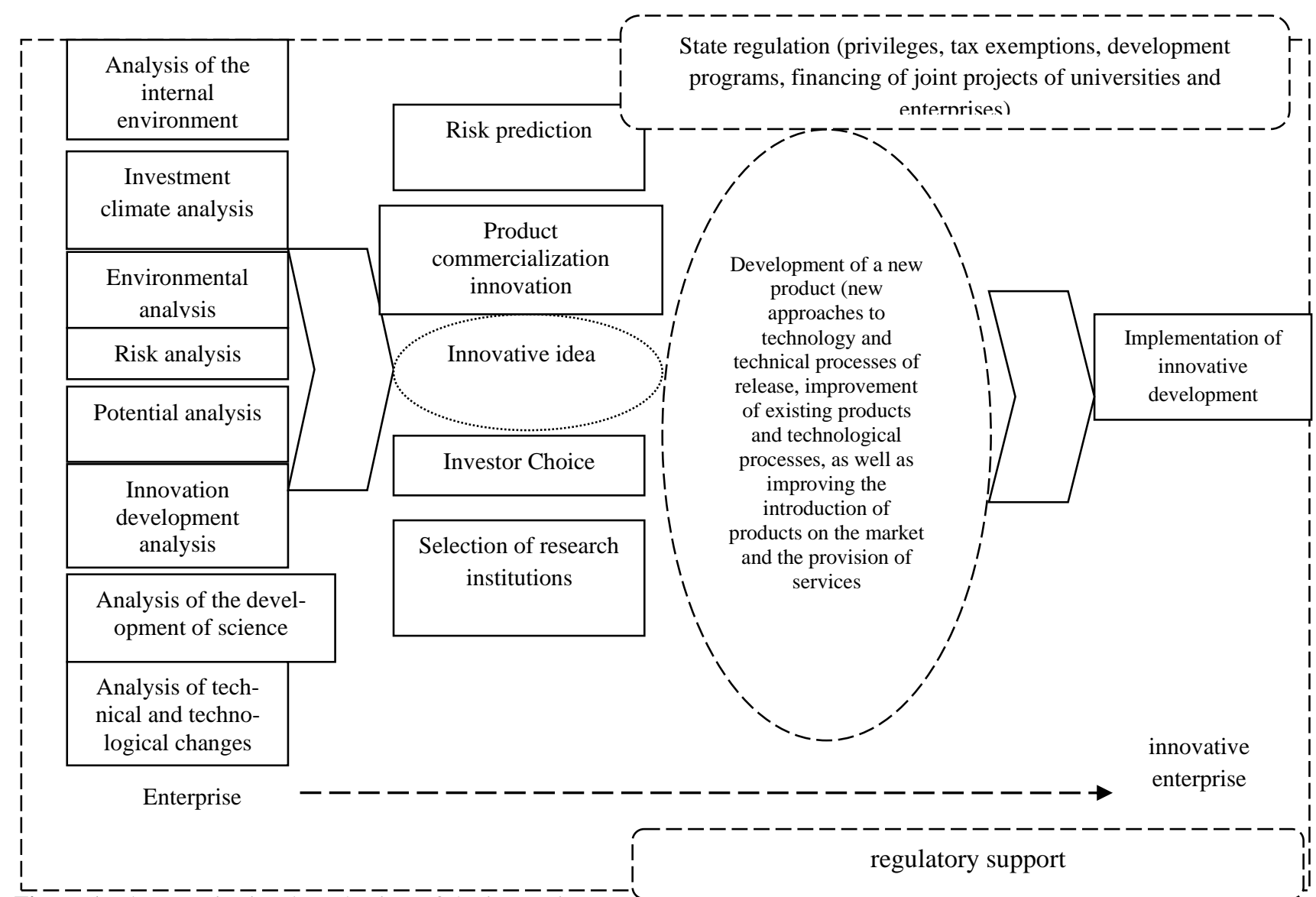

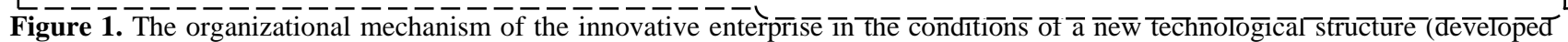
by the author on the basis of $[8,13,14,15])$

Commercialization as one of the stages of innovative activity of the enterprise, the result of research and development, the process, the practical use of scientific developments, the promotion of the sale of innovations, provides ownership. Development or the right to use a technological process may be used only on a paid basis. The organizational mechanism of an innovative enterprise in the conditions of a new technological structure will look as follows (Figure 1).

Conclusions. Sustainable development innovative enterprise, having received the necessary amount of financing, will be able to produce and market an innovative product that requires the present in the face of technological changes and environmental changes. The settled and close feedback between all subjects of the innovation process will ensure the effective interaction of the elements of the national innovation system in order to accelerate the pace of economic growth and promote new technological solutions and developments in the period of the new technological structure. The developed organizational mechanism for the formation of an innovative enterprise will provide not only the emergence of new innovative enterprises, but also the opportunity for already functioning enterprises to obtain the status of innovative.

\section{ЛIТЕРАТУРА}

1. Про інноваційну діяльність Закон України від 05.12.2012p. № 40-IV. Дата оновлення 16.10.12: URL: https://zakon.rada.gov.ua/laws/show/40-15 (дата звернення 03.09.2019).

2. Шваб К. Четвертая промышленная революция. Москва: Эксмо, 2016. $230 \mathrm{c.}$

3. Кондратьев Н.Д. Большие циклы конъюнктуры и теория предвидения. Москва: Экономика, 2002. 767 с

4. Шумпетер Й. Теория экономического развития. Исследование предпринимательской прибыли, капитала и цикла экономической конъюнктуры. Москва: Прогресс, 1992. $231 \mathrm{c}$.

5. Ефремов В.С. Бизнес-системы постиндустриального мира. Менеджмент за рубежом. 1999. №5. С.15-23.
6. Липсиц, И.В. Экономика Москва: ИНФРА-М, 2018. 607 с.

7. The Global Innovation Index (GII) 2019: URL: https://www.globalinnovationindex.org/Home

8. Павлов В.В. (2019). Стимулювання розвитку інноваційного середовища України через активізацію державноприватного партнерства. Інноваційні економічні механізми для розвитку підприємств, регіонів, краӥн: Матеріали міжнародної науково-практичної конференції, 15-16 лютого, Київ, Україна, 29-34.

9. The ICC Intellectual Property Roadmap - Current and emerging issues for business and policymakers https://iccwbo.org/publication/icc-intellectual-propertyroadmap-current-emerging-issues-business-policymakers/ 
10. What is Horizon 2020. URL: https://ec.europa.eu/programmes/horizon2020/what-horizon2020 (дата звернення 28.08.2019)

11. The Global Innovation Index (GII) 2019 URL: https://www.globalinnovationindex.org/Home

12. Рамкова програма «Горизонт-2020» URL: https://www.kmu.gov.ua/storage/app/media/uploadedfiles/broshura-gorizont-2020-1201.pdf (дата звернення 16.05.2019)

13. Андрощук Г.О. (2018) Державна політика в сфері інтелектуальної власності: ключові питання Проблеми та перс- пективи розвитку інновачійної діяльності в Украйні : матеріали XI Міжнародного бізнес форуму, 22 березня, Київ, Україна, $19-23$.

14. «Про схвалення Стратегії розвитку сфери інноваційної діяльності на період до 2030»: Розпорядження КМУ від 10.07.2019 p. № URL: https://zakon.rada.gov.ua/laws/show/526-2019$\% \mathrm{D} 1 \% 80$ (дата звернення: 03.08.2019).

15. Гудзь О.Є. Інноваційне підприємництво. Київ: Планета людей, 2018.187 с.

\section{REFERENCES}

1. Pro innovatsiynu diyalnist: Zakon Ukrainy vid 05.12.2012r. № 40-IV. URL: https://zakon.rada.gov.ua/laws/show/40-15.

2. Shvab K. (2016) Chetvertaia promyshlennaia revoliutsyia [Fourth industrial revolution]. Moskva: Eksmo [in Russian].

3. Kondratev M. (2002) Bolshye tsykly koniunktury i teoryia predvidenyia. [Big business cycles and foresight theory]. Moskva: Ekonomika [in Russian].

4. Shumpeter Y. (1992) Teoryia ekonomycheskoho razvytiia Isledovanie predprynymatelskoi prybyli, kapitala y tsykla ekonomycheskoi koniunktury. [Theory of economic development. Study of entrepreneurial profit, capital and the economic cycle]. Moskrva: Prohress [in Russian]

5. Efremov V.S. (1999) Byznes-systemy postyindustrialnoho mira. [Business systems of the post-industrial world]. Menedzhment za rubezhom. (vol.5).

6. Lypsyts, Y.V. (2018) Ekonomika. [Economy] Moskva: IN FRA-M [in Russian]

8. Pavlov V.V. (2019). Stymuliuvannia rozvytku innovatsiinoho seredovyshcha Ukrainy cherez aktyvizatsiiu derzhavno- pryvatnoho partnerstva. Innovatsiini ekonomichni mekhanizmy dlia rozvytku pidpryiemstv, rehioniv, krain: Materialy mizhnarodnoi naukovo-praktychnoi konferentsii, 15-16 liutoho, Kyiv, Ukraina 2019, 29-34.

12. Ramkova prohrama «Horyzont-2020» URL: https://www.kmu.gov.ua/storage/app/media/uploadedfiles/broshura-gorizont-2020-1201.pdf

13. Androshchuk H.O. (2018) Derzhavna polityka v sferi intelektualnoi vlasnosti: kliuchovi pytannia Problemy ta perspektyvy rozvytku innovatsiinoi diialnosti $\mathrm{v}$ Ukraini : materialy KhI Mizhnarodnoho biznes forumu, 22 bereznia, Kyiv, Ukraina, $19-23$.

14. «Pro skhvalennia Stratehii rozvytku sfery innovatsiinoi diialnosti na period do 2030»: Rozporiadzhennia KMU vid 10.07.2019 r. $\quad$ № $526-$ r. $\quad$ URL: https://zakon.rada.gov.ua/laws/show/526-2019-\%D1\%80

15. Hudz O. (2018) Innovatsiine pidpryiemnytstvo [Innovative entrepreneurship]/ Kyiv, Planeta liudei [in Ukrainian]. 